\title{
Indicators of microbial drinking and recreational water quality
}

\section{Daiva Staradumskytè,}

\section{Algimantas Paulauskas}

Vytautas Magnus University,

Vileikos 8,

LT-44248 Kaunas,

Lithuania
The microbiological examination of water is used worldwide to monitor and control the quality and safety of various types of water. These include potable water (water intended for drinking or use in food preparation), treated recreational water (swimming pools, spa pools, and hydrotherapy pools), and untreated water used for recreational purposes such as sea, river and lake water. In this study we analyzed 844 potable water samples (tap water - 531, well water - 232, borehole water - 81) collected from different places in Kaunas and Marijampole districts and recreational water from 72 rivers and lakes which were analyzed every two weeks by membrane filtration. The commonest microbiological tests done on water are for coliform bacteria (Citrobacter spp., Enterobacter spp., Klebsiella spp., Serratia spp., Enterobacter spp.), Escherichia coli (or fecal coliform) and Enterococci (or fecal Streptococcus) by ISO standards.

Key words: coliform bacteria, water quality, microbiological indicators

\section{INTRODUCTION}

Water pollution caused by fecal contamination is a serious problem due to the potential of contracting diseases from pathogens (disease causing organisms). Frequently, concentrations of pathogens from fecal contamination are small, and the number of different possible pathogens is large (Department, 2002). Ensuring the microbiological quality of potable and recreational water to protect public health requires the detection of coliform bacteria. Coliforms come from the same sources as pathogenic organisms. In particular, Escherichia

\footnotetext{
* Corresponding author. E-mail: a.paulauskas@gmf.vdu.lt
}

coli and Enterococci as indicators of human fecal contamination and possibly associated with human enteric pathogens. As a result, testing for coliform bacteria can be a reasonable indication of whether other pathogenic bacteria are present.

Coliform (thermotolerant) bacteria are a commonly-used bacterial indicator of sanitary quality of food and water. They are defined as rod-shaped, Gram-negative, non-spore forming bacteria which can ferment lactose with the production of acid and gas when incubated at $35-37^{\circ} \mathrm{C}$. While coliforms themselves usually are not a cause of serious illness, they are easy to culture and their presence is used to indicate that other pathogenic organisms of fecal origin may be present (Fisher, Phillips, 2009). 
Total coliforms include bacteria that are found in the soil, in water that has been influenced by surface water, and in human or animal waste. Fecal coliforms are the group of the total coliforms that are considered to be present specifically in the gut and feces of warm-blooded animals. As the origins of fecal coliforms are more specific than the origins of the more general total coliform group of bacteria, fecal coliforms are considered a more accurate indication of animal or human waste than the total coliforms (Department, 2002).

Escherichia coli, a rod-shaped member of the coliform group, can be distinguished from most other coliforms by its ability to ferment lactose at $44^{\circ} \mathrm{C}$ in the fecal coliform test and by its growth and color reaction on certain types of culture media. Unlike general coliform group, Escherichia coli is the major species in the fecal coliform group. Of the five general groups of bacteria that comprise the total coliforms, only Escherichia coli is generally not found growing and reproducing in the environment. Consequently, Escherichia coli is considered to be the species of coliform bacteria that is the best indicator of fecal pollution and the possible presence of pathogens (Ascbolt et al., 2001).

Most coliform bacteria do not cause disease. However, some rare strains of Escherichia coli, particularly strain 0157:H7, can cause serious illness. Recent outbreaks of disease caused by E. coli 0157:H7 have generated much public concern about this organism. Escherichia coli 0157:H7 has been found in cattle, chickens, pigs, and sheep. Most of the reported human cases have been due to eating undercooked hamburgers. Cases of Escherichia coli 0157:H7 caused by contaminated drinking water supplies are rare (Department, 2002).

Enterococci are commonly found in the feces of humans and other warm-blooded animals. Although some strains are ubiquitous and not related to fecal pollution, the presence of enterococci in water is an indication of fecal pollution and the possible presence of enteric pathogens. Epidemiological studies have led to the development of criteria which can be used to promulgate recreational water standards based on the established relationship between health effects and water quality (Oshiro, 2002).

Enterococci are Gram-positive cocci that often occur in pairs (diplococci) or short chains and are difficult to distinguish from Streptococci by physical characteristics alone, enterococci are tolerant to a wide range of environmental conditions: extreme temperature $\left(10-45^{\circ} \mathrm{C}\right), \mathrm{pH}(4.5-10.0)$ (ISO 19250, 2010).

As a result, testing for coliform bacteria can be a reasonable indication of whether other pathogenic bacteria are present. A number of bacteria occur naturally in freshwater streams. Some are found living in water and sediments as photosynthetic autotrophs or saphrophytes living on dead matter. Others exist in or on other organisms as mutual symbiotes (providing some benefit to the host organisms in exchange for a place to live), commensuals (neither helping nor harming the host), or parasites (utilizing the host in a way that causes harm). Certain bacteria that live in the intestinal tract of animals are essential for the recovery of nutrients from digested food. Millions of these naturally occurring organisms are passed out of the body with fecal waste (Oshiro, 2002).

\section{MATERIALS AND METHODS}

Samples were obtained from the following sources: tap water, well water, borehole water, recreational water. Samples were transported to the laboratory immediately after collection. Various dilutions and volumes were filtered through membrane. A $100 \mathrm{ml}$ volume of water sample is drawn through a membrane filter $(0.45 \mu \mathrm{m}$ pore size $)$ using a vacuum pump. The filter is placed on a petri dish containing selective agar. Membranes were transferred on Tergitol 7 agar (T7A) which is used selectively for coliform bacteria, when incubated at elevated temperatures $\left(36 \pm 2{ }^{\circ} \mathrm{C}, 44 \pm 0.5^{\circ} \mathrm{C}, 24 \mathrm{~h}\right)$. All red, yellow, orange and other colonies (Fig. 1) are cultivated for confirmation in Tryptone water for indole test and Tryptone soy agar for oxidase test. Bacteria when oxidase test is negative, indole is negative are confirmed as coliform bacteria, and bacteria when oxidase test is negative, indole test is positive are confirmed as Escherichia coli (LST 9308-1, 2001). For identification of coliform bacteria to the species level biochemical tests (Triple Sugar Iron Agar, Lysine Iron Agar, Urease Test Broth, RapID oneE system) are used. SlanetzBartley agar which is used selectively for fecal Streptococcus, when incubated at elevated temperatures $\left(36 \pm 2{ }^{\circ} \mathrm{C}, 48 \mathrm{~h}\right)$, and Bile Esculin agar is used for 


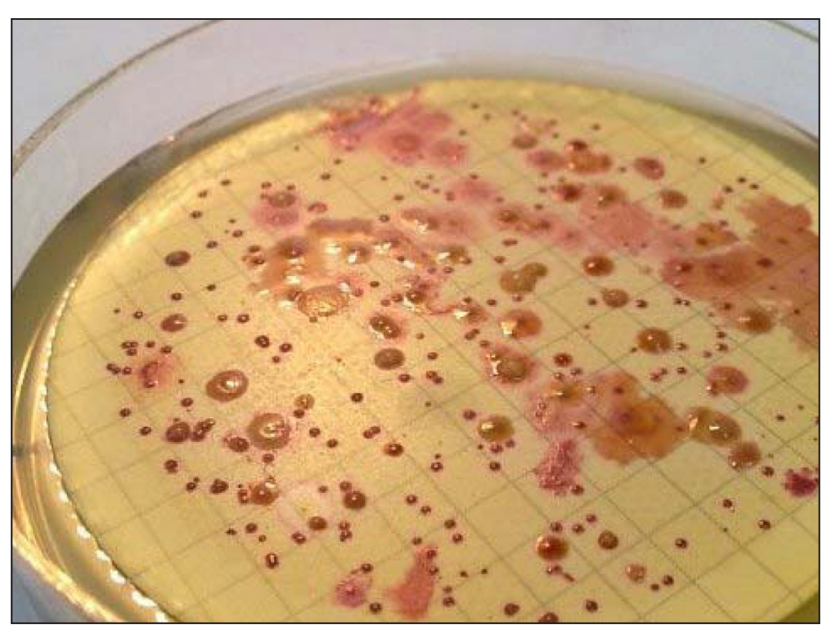

Fig. 1. Thermotolerant coliform bacteria on Tergitol 7 agar

fecal Streptococcus confirmation $\left(44 \pm 0.5^{\circ} \mathrm{C}, 2 \mathrm{~h}\right)$ (Fig. $2 \mathrm{a}, \mathrm{b}$ ). All red or brown colonies on the membrane from Slanetz-Bartley agar are calculated and membrane is transferred on Bile Esculin agar, if colonies are black-brown surrounding the medium after two hours, it is a confirmation of fecal Streptococcus (LST 7899-2, 2001).

Bacteriological quality of different water sources. Lithuanian hygiene norms (HN) are specified by the value (Table 1) of microbiological water pollution in drinking (HN 24:2003) and recreational (HN 92:2007) water.

\section{RESULTS AND DISCUSSION}

From May till December 2010, 303 recreational water samples from Kaunas and Marijampolè districts were collected from 72 rivers and lakes for microbiological tests. All samples were tested for fecal Streptococcus and a lot of them for Escherichia coli. As we see in the diagram (Fig. 3), almost in all water samples fecal Streptococcus was detected and a quarter of samples exceeded the criteria of hygiene norm. Lakes and rivers with exceeded fecal Streptococcus number always were the same in all summer months of their popularity. We detected that in really hot weather Streptococcus numbers were less compared with breezy weather. As we see, in December 6 water samples were tested and only in one fecal Streptococcus was not detected. It shows that fecal Streptococcus can also survive in low temperature.

As we see in the diagram (Fig. 4), almost in all water samples presumptive thermotolerant bacilli

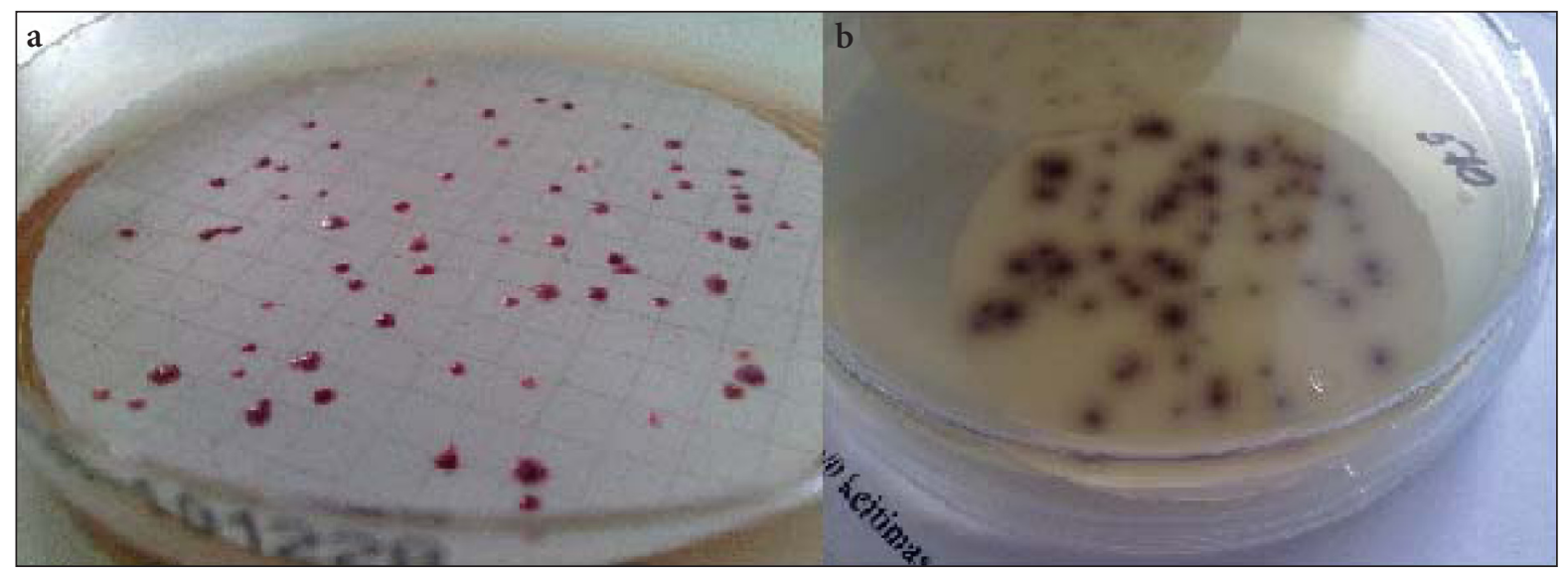

Fig. 2. a) Enterococci on Slanetz-Bartley agar,

b) Confirmed enterococci on Bile Esculin agar

Table 1. Different sources values of bacteriological pollution

\begin{tabular}{cc}
\hline Organism & Guidelines value \\
\hline Water intended for drinking & Must not be detectable in any $100 \mathrm{ml}$ sample \\
\hline Escherichia coli & Must not be detectable in any $100 \mathrm{ml}$ sample \\
\hline Enterococcus spp. & \\
\hline Recreational water & Not more than $1000 \mathrm{CFU} / 100 \mathrm{ml}$ sample \\
\hline Escherichia coli & Not more than $100 \mathrm{CFU} / 100 \mathrm{ml}$ sample \\
\hline Enterococcus spp. &
\end{tabular}




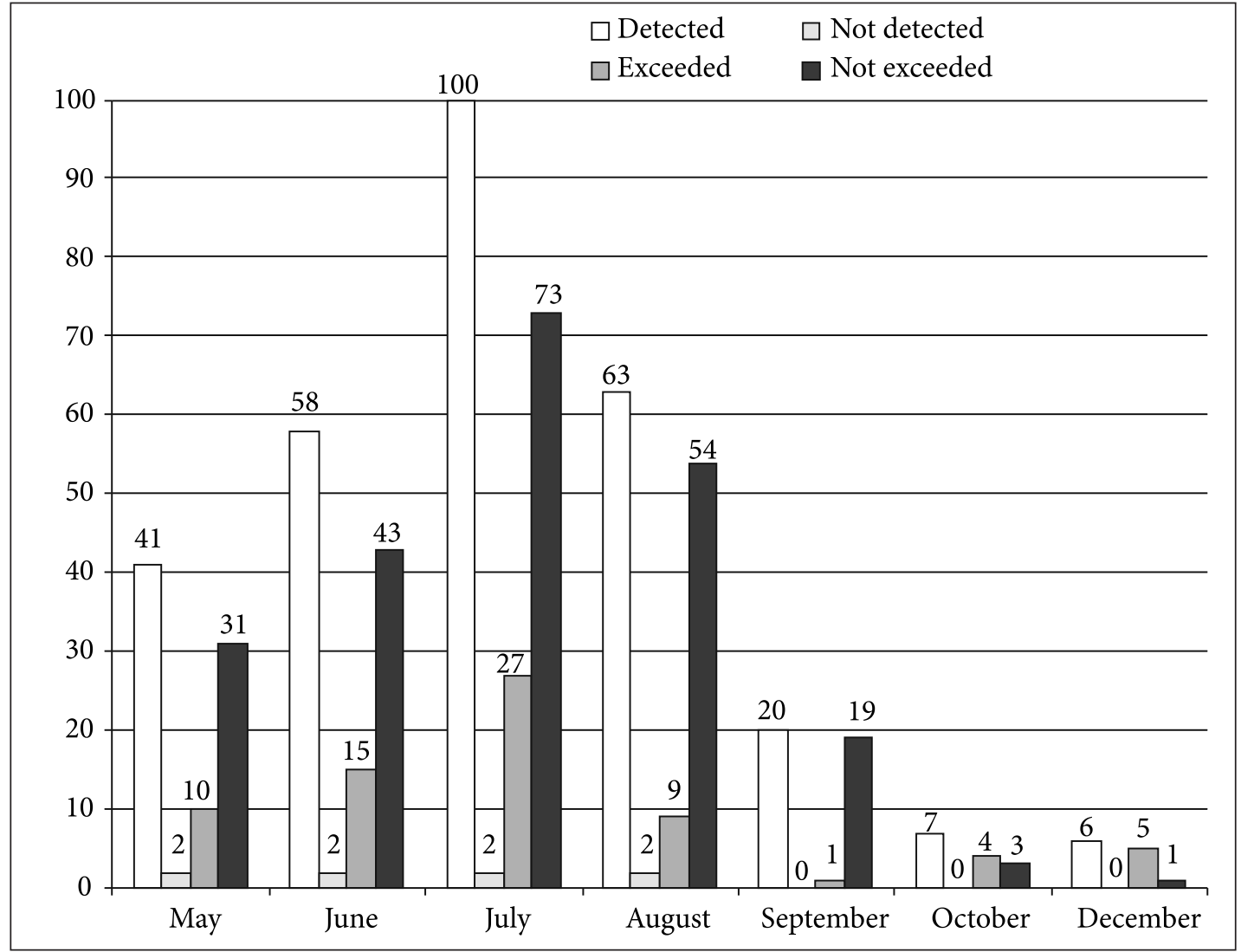

Fig. 3. Detection of fecal Streptococcus

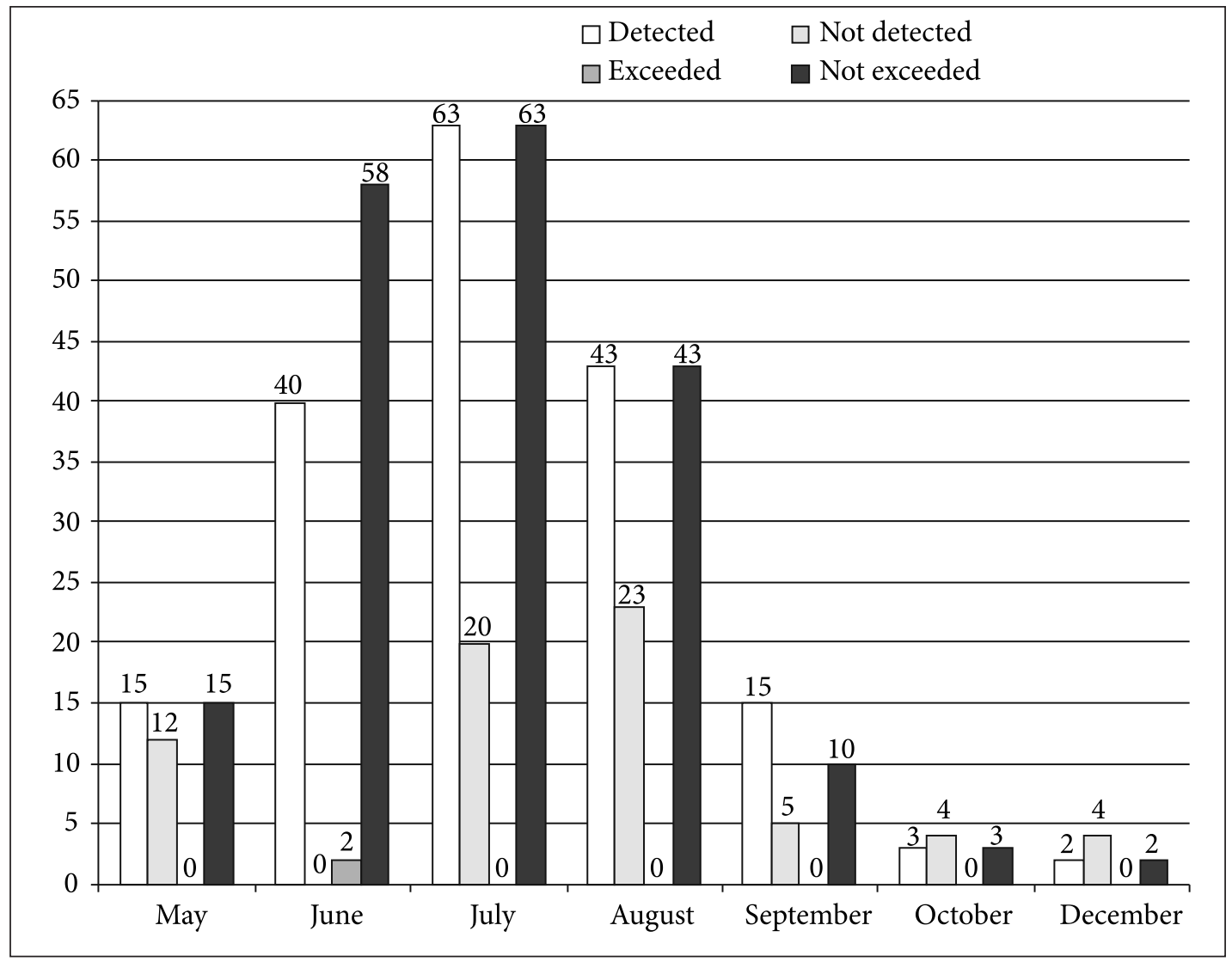

Fig. 4. Detection of E. coli 
(Escherichia coli) were detected. But the difference between fecal Streptococcus and Escherichia coli is that only in two water samples the criteria number by HN 92:2007 was exceeded. Escherichia coli in water show fresh fecal pollution. As we can see from the diagram, throughout all research period we can find fresh fecal pollution in recreational water.
Some samples with exceeded fecal pollution were tested for Salmonella spp., but in none of them Salmonella spp. was detected in this term.

From September till December 2010, 844 potable water samples from different Kaunas and Marijampole districts were tested. As we see in Table 2 and the diagram of Fig. 5, in tap water we

Table 2. Potable water type and detected bacteria

\begin{tabular}{|c|c|c|c|c|}
\hline Month & Potable water type & $\begin{array}{c}\text { Coliform } \\
\text { bacteria }\end{array}$ & E. coli & Enterococcus \\
\hline \multirow{3}{*}{ September } & tap water & 32 & 0 & 0 \\
\hline & well water & 6 & 16 & 53 \\
\hline & borehole water & 1 & 0 & 0 \\
\hline \multirow{3}{*}{ October } & tap water & 36 & 1 & 1 \\
\hline & well water & 11 & 10 & 24 \\
\hline & borehole water & 0 & 1 & 0 \\
\hline \multirow{3}{*}{ November } & tap water & 23 & 0 & 1 \\
\hline & well water & 3 & 14 & 23 \\
\hline & borehole water & 0 & 0 & 0 \\
\hline \multirow{3}{*}{ December } & tap water & 9 & 0 & 0 \\
\hline & well water & 2 & 3 & 6 \\
\hline & borehole water & 0 & 0 & 0 \\
\hline
\end{tabular}

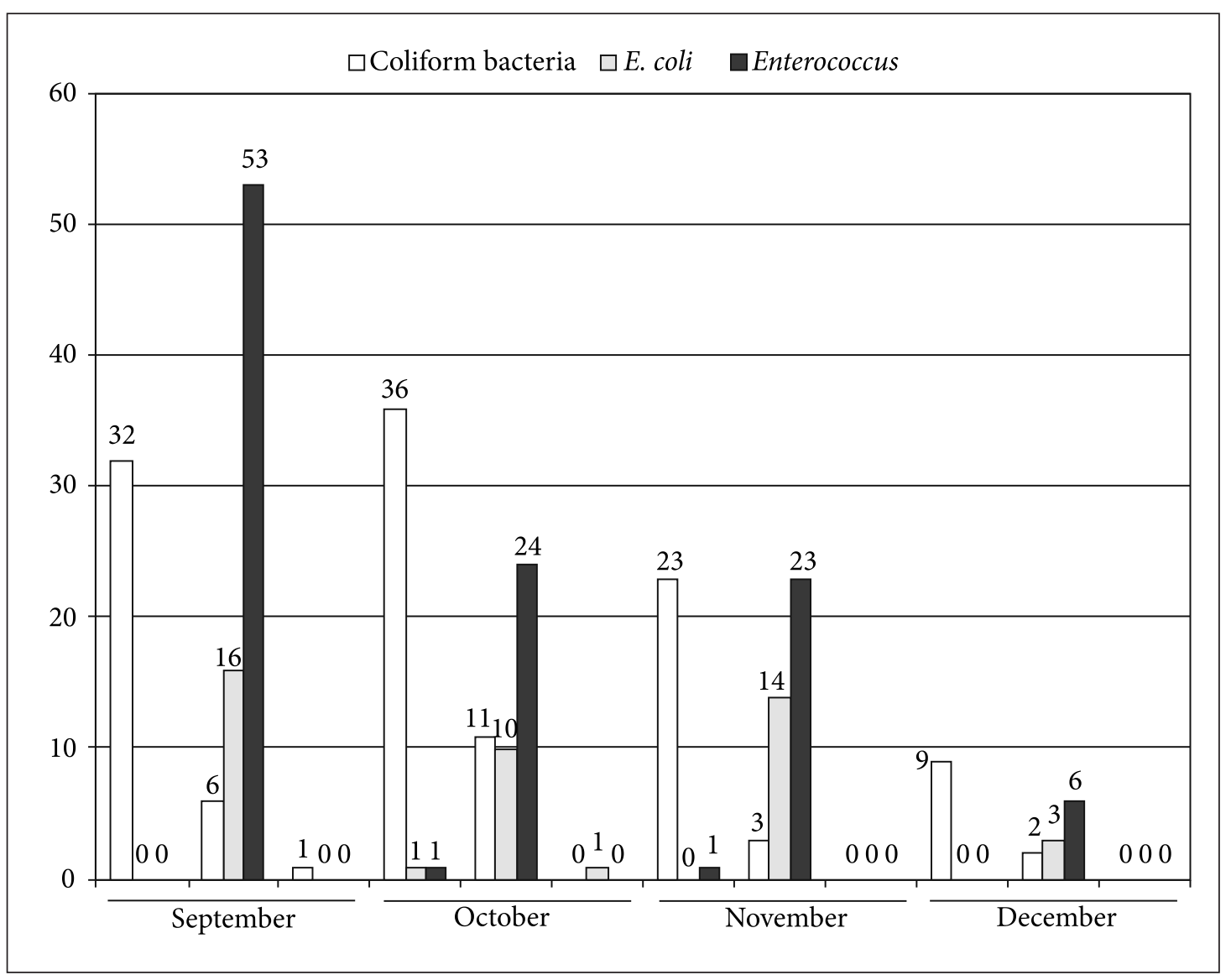

Fig. 5. Diagram of potable water pollution 
can find only coliform bacteria. Tap water quality is good but people do not take care of faucets.

The quality of well water is not satisfactory due to environmental contamination. With thaw, flood water in shaft wells can access various contaminants that can adversely affect health. In a lot of well water samples thermotolerant bacteria $E s$ cherichia coli, coliform bacteria (Citrobacter spp., Enterobacter spp., Klebsiella spp.) and fecal Streptococcus were found. Well water quality may be affected by the location of a well. Many wells are in rural, suburban, collective and individual garden plots where there is no central water supply system and wells may be dug near the barn or outdoor toilets, hence they may be polluted with fecal bacteria.

Water quality of boreholes is good. Fecal pollution was detected only in two samples.

\section{CONCLUSIONS}

Bacteriological contamination of recreational water persists throughout the year despite the fact that the swimming season is only from May till September. As we see from the research, some of these biological indicators are stronger in cooler weather than in sunny days during the summer season.

Potable water is contaminated with coliform bacteria apparently for the reason that people do not look after faucets in a proper manner. However, water quality of wells is really unsatisfactory in Lithuania. Many wells are dug in wrong places, outside the guidelines. This is most often found in old homesteads.

Microbiological investigations showed borehole water to be of really good quality.

\section{ACKNOWLEDGEMENTS}

We express our thanks to the personnel of National Public Health Surveillance Laboratory (NPHSL), Kaunas Department, Microbiological Subunit, for the assistance in investigations.

Received 29 October 2011 Accepted 22 April 2012
References

1. Department of the Environment, The Microbiology of Drinking Water - Water Quality and Public Health. 2002; Part 1.

2. Fisher K, Phillips C. The ecology, epidemiology and virulence of Enterococcus. Microbiology 2009; 155(6): 1749-57.

3. Ascbolt NJ, Grabow WOK, Snozzi M. Indicators of microbial water quality. Water Quality Guidelines, Standards and Health: Assessment of risk and risk management for water-related infectious disease (IWA - SMITTSKYDDSINSTITUTET - WHO) 2001; 260-88.

4. Oshiro Robin K. Method 1106.1: enterococci in water by membrane filtration using membrane-Enterococcus-Esculin Iron Agar (mE-EIA), 2002; September, U. S. Environmental Protection Agency.

5. ISO 19250. 2010. Water quality - Detection Salmonella spp.

6. LST EN ISO 9308-1:2001 Vandens kokybè. Žarninių lazdelių (Escherichia coli) ir koliforminių bakterijų aptikimas ir skaičiavimas. 1 dalis. Membraninio filtravimo metodas (ISO 93081:2000).

7. LST EN ISO 7899-2:2001 Vandens kokybè. Žarninių enterokokų aptikimas ir skaičiavimas. 2 dalis. Membraninio filtravimo metodas (ISO 78992:2000).

8. Lietuvos higienos norma HN 24:2003 Geriamojo vandens saugos ir kokybès reikalavimai.

9. Lietuvos higienos norma HN 92:2007 Paplūdimiai ir jų maudyklų vandens kokybè.

10. Ashutosh Srivastava. Assessment of water quality of different water sources with special reference to faecal contamination, B. Sc. III sem. Roll No. 516115.

11. Information for a Healthy New York, Department of Health, Coliform Bacteria in Drinking Water Supplies.

12. Slanetz LW, Bartley CH. Numbers of enterococci in water, sewage, and feces determined by the membrane filter technique with an improved medium. Department of Bacteriology, University of New Hampshire, Durham, New Hampshire. J Bacteriol 1957; 74(5): 591-5. 
Daiva Staradumskyte், Algimantas Paulauskas

\section{MIKROBIOLOGINIAI INDIKATORIAI,} PARODANTYS GERIAMOJO IR REKREACINIO VANDENS KOKYBĘ

\section{Santrauka}

Vandens mikrobiologinis tyrimas atliekamas visame pasaulyje stebint ir kontroliuojant ịvairių vandens tipų kokybę ir saugumą. Tokiems tikslams yra tiriamas vandentiekio vanduo (skirtas gerti ir naudoti maisto ruošimui), apdoroti rekreaciniai vandenys (vertikalios vonios, SPA baseinai, plaukiojimo baseinai) ir neapdoroti vandens telkiniai (jūrų, upių ir ežerų vandenys). Šio tyrimo metu buvo analizuojami 844 geriamojo vandens šaltiniai (531 vandentiekis, 232 šuliniai, 81 gręžinys) iš skirtingų vietų Kauno ir Marijampolès rajonuose ir atvirų telkinių vandenys, esantys poilsio zonose (72 upès, ežerai), prie namų iškasti tvenkiniai. Atvirų vandens telkinių vandenys buvo tiriami kas dvi savaites naudojant membraninius filtrus. Atliekant mikrobiologinius tyrimus vandenyje ieškoma Citrobacter spp., Enterobacter spp., Klebsiella spp., Serratia spp., Enterobacter spp., Escherichia coli (arba fekalinių koliformų) ir enterokokų (arba fekalinių Streptococcus). Tyrimai atliekami pagal ISO standartus.

Raktažodžiai: fekaliniai koliformai, vandens kokybe், mikrobiologiniai indikatoriai 